\title{
BMJ Open Job satisfaction, work commitment and intention to leave among pharmacists: a cross-sectional study
}

\author{
Nedaa Al-Muallem, ${ }^{1}$ Khaled Mohammed Al-Surimi ${ }^{01,2,3}$
}

To cite: Al-Muallem N, AlSurimi KM. Job satisfaction, work commitment and intention to leave among pharmacists: a cross-sectional study. BMJ Open 2019;9:e024448. doi:10.1136/ bmjopen-2018-024448

- Prepublication history for this paper is available online. To view these files, please visit the journal online (http://dx.doi. org/10.1136/bmjopen-2018024448).

Received 06 June 2018 Revised 09 August 2019 Accepted 20 August 2019
Check for updates

(C) Author(s) (or their employer(s)) 2019. Re-use permitted under CC BY-NC. No commercial re-use. See rights and permissions. Published by BMJ.

${ }^{1}$ Department of Health System Management, College of Public Health and Health Informatics, King Saud bin Abdulaziz University for Health Sciences, Riyadh, Saudi Arabia

${ }^{2}$ Department of Primary Care and Public Health, School of Public Health, Imperial College London School of Public Health, London, UK

${ }^{3}$ King Abdullah International Medical Research Center, Riyadh, Saudi Arabia

Correspondence to Dr Khaled Mohammed AlSurimi; kalsurimi@gmail.com

\section{ABSTRACT}

Objectives We assessed job satisfaction, work commitment and intention to leave among pharmacists working in different healthcare settings in Saudi Arabia. Design This was a cross-sectional study utilising a previously validated questionnaire.

Setting We surveyed the workforce at different healthcare settings in Riyadh, Saudi Arabia.

Participants The participants were pharmacists licensed by the Saudi Commission for Health Specialties.

Outcome measures We examined job satisfaction, work commitment and intention to leave.

Results In total, 325 out of 515 pharmacists completed the questionnaire, yielding a response rate of $63 \%$. Over half of them were women $(57.8 \%), 78.2 \%$ were Saudi Arabian nationals and $61.8 \%$ were married. The majority $(88.1 \%)$ worked between 36 and 44 hours per week; $96.6 \%$ were full-time employees, and $63.4 \%$ were government employees working in public hospitals or primary healthcare centres. Although most of the pharmacists were satisfied (satisfied and slightly satisfied) with their current job $(39.1 \%$ and $24.6 \%$, respectively), about two-thirds $(61.9 \%)$ had the intention to leave. Multiple logistic regression analysis showed that the most important predictors of pharmacists' intentions to leave were related to job satisfaction and work commitment ( $\mathrm{OR}=0.923 ; 95 \% \mathrm{Cl} 0.899$ to $0.947 ; \mathrm{p}<0.001$ and $\mathrm{OR}=1.044 ; 95 \% \mathrm{Cl} 1.014$ to $1.08 ; p=0.004$, respectively), whereas respondents' demographic characteristics had no effect.

Conclusions Although the pharmacists surveyed were satisfied and committed to their current job, they had the intention to leave. Further research is recommended to clarify why pharmacists in Saudi Arabia have the intention to leave their pharmacy practice job.

\section{BACKGROUND}

In addition to managerial and administrative roles, pharmacists have become more clinically involved in patient care at many points in healthcare system. These emerging roles for pharmacists have increased the need for qualified individuals to occupy the position. The employment of pharmacists is projected to increase by $3 \%$ between 2014 and 2024, which is slower than the average for all healthcare occupations. ${ }^{2}$ The traditional role of the pharmacists in Saudi Arabia was limited

\section{Strengths and limitations of this study}

This study depended on a valid list of licensed pharmacists by the Saudi Commission for Health Specialties, who are working in different healthcare settings in capital city, Riyadh.

- This is the first study, to the best of our knowledge, being conducted in Saudi Arabia studying together the pharmacists' job satisfaction, work commitment and intention to leave.

- This study provides local empirical evidence for devising health polices to improving staff retention, satisfaction and work commitment.

> Our results were the self-reported perceptions of the participants; therefore, they may be subject to bias and ungeneralisable to all pharmacists in Saudi Arabia.

in dispensing medications; however this role has changed recently to include other related medications issues, for example counselling patients in the hospital and community pharmacies, and getting involved in advising physicians about the appropriate therapeutic dose and drug-related problems such as drugdrug interactions ${ }^{3}$ in different clinical settings ambulatory care, oncology and haematology, cardiology, among others. ${ }^{4}$ However, job turnover among pharmacists is relatively high and the issue of retaining pharmacists is a major concern among institutional managers. ${ }^{5}$ One of the most significant factors that affects job turnover is job satisfaction. Job satisfaction has been defined as 'the extent to which people like (satisfaction) or dislike (dissatisfaction) their job'. ${ }^{6}$ Intrinsic and extrinsic job characteristics are the two main factors that influence the level of job satisfaction. Intrinsic factors include performance, challenge and autonomy and depend on the characteristics of an employee, and extrinsic factors include workload, job security, promotion opportunities and relationships with co-workers. ${ }^{7}$

As far as the satisfaction of health professional is concerned, previous studies indicated that $40 \%$ of primary healthcare female 
nurses in Saudi Arabia were dissatisfied and had turnover intentions to leave. ${ }^{8}$ The most common influencing factors that contribute to Saudi's female nurses are the negative public attitudes and perception towards the nursing profession and the nature of their work that needed mixing with men. ${ }^{8}$ Likewise, it has been reported about $25.2 \%$ of physicians working in Saudi primary healthcare centres are burnout and might among the potential factor of intention to leave. ${ }^{9}$ Worldwide, intentions to leave among health worker professionals are an increasing problem that affects the functioning of any healthcare system, especially in developing countries. ${ }^{10}$

Both international and regional studies have identified determinants of professional satisfaction among healthcare workers, including pharmacists. Among healthcare workers, $69 \%$ of turnover intentions are significantly associated with job satisfaction and motivation from managers. ${ }^{11}$ Some psychological morbidity is also associated with reduced job satisfaction. ${ }^{12} \mathrm{~A}$ high level of employee stress, which is related to a high workload, has a significant impact on staff performance. ${ }^{13}$ Longer working hours also contribute to reduced job satisfaction. Job autonomy is another variable that influences job satisfaction. ${ }^{7}$ In addition, sociodemographic characteristics, occupation, educational background, years of service and income have significant effects on the job satisfaction of healthcare staff. ${ }^{14}$ More than $68 \%$ of pharmacists have experienced job stress. ${ }^{15}$ Intrinsic factors such as job security are among the primary determinants of pharmacists' job satisfaction. ${ }^{16}$ Lack of financial support and acceptance by medical staff are also barriers to the professional satisfaction of pharmacists. ${ }^{17}$ A high-pressure working environment is another factor that frequently influences pharmacists' job satisfaction. ${ }^{18}$

The turnover intention of pharmacists is growing as a result of factors including job satisfaction, age, sex and strength of desire to practice pharmacy. ${ }^{19}$ Reportedly, the turnover rate among pharmacists in the USA is $14.4 \%$ for several reasons: promotion opportunities, pay and benefits, working hours, educational development opportunities and professional challenges. ${ }^{20}$ The annual turnover rates are greater among women than men $(15 \%$ and $9.7 \%$, respectively). ${ }^{21}$

Several studies have addressed pharmacists' job satisfaction globally. In the USA, both community and hospital pharmacists report moderate levels of job satisfaction, which the authors link to stress levels. ${ }^{22}$ Another study found that age, income and practice site can predict job satisfaction among practicing pharmacists. ${ }^{23}$ A study involving pharmacists working in chain pharmacies reported that their job satisfaction was lower (53\%) than that of pharmacists working in other settings. ${ }^{24}$ In addition, several studies conducted in the UK have demonstrated a link between increasing pharmacist job dissatisfaction and stress related to high workload and its impact on community pharmacists. ${ }^{25}$ Pharmacists' performance can be affected by many factors related to workload and working environment. ${ }^{26}$ Job satisfaction is an important contributory factor to motivation and productivity among pharmacists. ${ }^{11}$

The indicators of job satisfaction include employee effectiveness, good mental and emotional status, behaviour that improves worker functioning and performance and good professional relationships with staff, colleagues and physicians. ${ }^{27} 28$ Also, quality of work is considered a measure of job satisfaction by the European Commission. ${ }^{7}$ Job satisfaction, turnover intention and patient care and safety are important contributors to pharmacists' quality of work life. ${ }^{29}$ Studies have shown there are significant associations between burnout and poor patient safety such as medical errors. ${ }^{30}$ Moreover, one of the predictors of burnout among healthcare professionals is job insecurity. ${ }^{31}$

Work commitment is highly related to duration of employment and age. Younger pharmacists have a lower level of satisfaction and organisational attachment. ${ }^{32}$ Other predictors of organisational commitment include supervisor support, perceptions of the effect of the pharmaceutical care movement and practice setting. ${ }^{33}$ High job satisfaction will positively affect work commitment, consequently decreasing turnover intention among pharmacists. $^{34}$

Medication errors lead to increased healthcare costs and morbidity and mortality rates. ${ }^{35}$ Pharmacists have a specific role in reducing medication errors by performing interventions that improve medication safety, such as risk assessments in clinical pharmacies and developing methods to detect patients at high risk of adverse drug reactions. ${ }^{35}$ One of the recommendations to reduce medication errors is to use the 'five rights': the right dose, right patient, right drug, right route and right time. ${ }^{36}$ Of dispensing errors, $46 \%$ are related to organisational factors, and $41 \%$ are related to individual factors. ${ }^{37}$ The number of medication errors is influenced by pharmacists' years of practice and recognition of stress. A better perception of safety culture is an indicator of a decreased number of medication errors. ${ }^{38}$ A high level of pharmacist job satisfaction has direct positive impact on the safety of medication dispensing, and this in turn has a huge impact on the quality of patient care. ${ }^{39}$

Among the Arab countries, low satisfaction among community pharmacists has been reported in Jordan, and Yemeni pharmacists have expressed dissatisfaction with their working conditions and opportunities. ${ }^{40}{ }^{41}$ In 2014, a high rate of job satisfaction was reported among Saudi Arabian healthcare professionals. ${ }^{13}$ However, in a 2015 study, Saudi Arabian pharmacists, especially community pharmacists and those working in dispensaries and chain pharmacies, reported a low level of job satisfaction. ${ }^{42}$ This is inconsistent with the findings of a study conducted in 2005, which indicated that the job satisfaction of Saudi Arabian community pharmacists is high. ${ }^{27}$ To the best of our knowledge, only two studies have investigated job satisfaction among Saudi Arabian pharmacists. Therefore, in this study, we assessed the level of job satisfaction and work commitment, and their impact on turnover 
rate and intention to leave, among pharmacists working in different healthcare settings in Saudi Arabia. Our findings will inform and advise policymakers and health planners in the development of an evidence-based retention policy for health human resources, both in general and in pharmacists in particular.

\section{METHODS}

\section{Settings and participants}

This study involved pharmacists working at different healthcare settings in Riyadh, Saudi Arabia, including public and private hospitals, community chain pharmacies, community independent pharmacies, primary care centre pharmacies, industrial pharmacies and academic pharmacies. The study population comprised pharmacists licensed by the Saudi Commission for Health Specialties and working in the Riyadh region, regardless of their sex and workplace.

\section{Methods of measurement}

Based on the data provided by the Saudi Commission for Health Specialties, we calculated the required sample size. Using an online sample calculator (Raosoft, Inc, Seattle, Washington, USA; http://www.raosoft.com/ samplesize.html), with a chosen accepted error margin of $5 \%$, a $95 \%$ confidence level and a $50 \%$ response distribution within the pharmacist population in Riyadh, the minimum required sample size was 309 participants. Taking into consideration a non-respondent rate of $20 \%$, the final targeted sample size was 387 participants. We sent a self-administered questionnaire to all 515 pharmacists licensed by the Saudi Commission for Health Specialties in Riyadh; thus, no sampling technique was applied. The self-administered questionnaire was combined with a letter that explained the purpose of the study and assured them of the confidentiality of their responses. Data were collected using an English version of a questionnaire developed and used in a Malaysian study by Chua et $a l^{43}$ to assess job satisfaction, organisation commitment and retention in the public workforce among pharmacists. Although the validity and reliability of the study tool has been reported in Malaysian study by Chua et $a l,{ }^{38}$ we have conducted a pilot study to test the reliability of the study tool in the Saudi context, and the Cronbach's alpha for the job satisfaction and work commitment scale were 0.94 and 0.77 , respectively. The questionnaire consisted of eight sections: sociodemographic characteristics, current job features, job satisfaction and work commitment (scored using a 6-point Likert scale ranging from strongly disagree to strongly agree and comprising 15 statements), overall satisfaction with their current job, intention to leave their current job, overall patient safety at their workplace and opinions on how to improve job satisfaction and work commitment among pharmacists working in Saudi Arabia. The questionnaires were sent to respondents as online survey via the validated emails list provided by Saudi Commission for Health Specialties in
Riyadh, and at end of survey, there was a link to submit and send back the completed survey.

\section{Statistical analysis}

All data were managed and analysed using SPSS V.22 (IBM Corp, Armonk, New York, USA). Both descriptive and analytical statistics were used as needed; categorical variables were presented as frequencies and percentages, and continuous variables as means and SD. Non-parametric tests, including the Mann-Whitney and Kruskal-Wallis tests, and the $\mathrm{X}^{2}$ test were used as appropriate, and multivariate logistic regression analysis was performed to determine the association between demographic variables, job satisfaction and work commitment and the participants' likelihood to leave their current job. A p value $<0.05 \%$ and $95 \%$ CI were used to indicate statistical significance.

\section{Patient and public involvement}

Patients were not involved.

\section{RESULTS}

\section{Sociodemographic characteristics of the participants}

In total, 325 of 515 pharmacists completed the study questionnaire, yielding a response rate of $63.1 \%$. The majority of the respondents were women $(\mathrm{n}=188,57.8 \%)$ and aged between 25 and 30 years $(35.7 \%)$. Of them, $78.2 \%$ were Saudi Arabian nationals, $61.8 \%$ were married and 52.6\% held a bachelor's degree. The average working hours of more than half of the respondents $(\mathrm{n}=171,52.6 \%)$ were between 36 and 44 hours, equating to full-time employment status. Of the respondents, $51.4 \%$ worked at public hospital pharmacies and filled the staff pharmacist position $(n=182,56.5 \%)$. Most participants had 6 to 15 years of experience (table 1 ).

\section{Job satisfaction and work commitment}

Table 2 shows the pharmacists' responses across all items of job satisfaction and work commitment. Approximately $60 \%$ of the respondents reported that they were satisfied with their job: they were happy going to work every day, they described their job to family and friends as a great job to have, the job provided them with opportunities to use their abilities, they had flexibility to choose any method of doing the job, they had sufficient freedom to use their own judgement in their job and they got a feeling of accomplishment from their work. However, $62 \%$ of the respondents said that they were not satisfied at the end of each working day, and they felt that the day had not been well spent. Forty-seven per cent were unsatisfied by the fringe benefits offered by their current job, and $36 \%$ felt unlucky to have their job.

Regarding work commitment, $83 \%$ of the respondents said that they were willing to put in effort beyond that normally expected to help the workplace be successful. More than $70 \%$ were proud to tell others that they are a part of their organisation and really cared about its fate. More than $60 \%$ of respondents were extremely glad that 


\begin{tabular}{|c|c|c|c|}
\hline Demographic characteristics & $\mathrm{n}(\%)$ & Demographic characteristics & n (\%) \\
\hline Sex & & $16-20$ & $42(12.9)$ \\
\hline Male & $137(42.2)$ & $>20$ & $28(8.6)$ \\
\hline Female & $188(57.8)$ & Current position & \\
\hline Age (years) & & Pharmacist manager/supervisor & $96(29.8)$ \\
\hline$<25$ & $14(4.3)$ & Pharmacist staff & $182(56.5)$ \\
\hline $25-30$ & $116(35.7)$ & Pharmacy owner & $2(0.6)$ \\
\hline $31-35$ & $94(28.9)$ & Others & $42(13)$ \\
\hline $36-40$ & $47(14.5)$ & Unknown & $3(0.9)$ \\
\hline
\end{tabular}

$>40$

54 (16.6)

Marital status

\begin{tabular}{|c|c|}
\hline Single & $113(34.8)$ \\
\hline Married & $201(61.8)$ \\
\hline Divorced & $11(3.4)$ \\
\hline \multicolumn{2}{|l|}{ Income/month (SR) } \\
\hline$<5000$ & $16(4.9)$ \\
\hline $5000-10000$ & $52(16.0)$ \\
\hline $11000-15000$ & $117(36.0)$ \\
\hline$>15000$ & $140(43.1)$ \\
\hline \multicolumn{2}{|l|}{ Nationality } \\
\hline Saudi Arabian & $254(78.2)$ \\
\hline Non-Saudi Arabian & $71(21.8)$ \\
\hline \multicolumn{2}{|l|}{ Highest level of education } \\
\hline Bachelor's degree & $171(52.6)$ \\
\hline Master's degree & $94(28.9)$ \\
\hline Pharm D & $36(11.1)$ \\
\hline $\mathrm{PhD}$ & $13(4.0)$ \\
\hline Other & $11(3.4)$ \\
\hline \multicolumn{2}{|c|}{ Average hours worked per week } \\
\hline$\leq 35$ & $33(10.2)$ \\
\hline $36-44$ & $171(52.6)$ \\
\hline$>44$ & $121(37.2)$ \\
\hline \multicolumn{2}{|l|}{ Employment status } \\
\hline Full-time & $314(96.6)$ \\
\hline Part-time & $11(3.4)$ \\
\hline \multicolumn{2}{|l|}{ Place of practice } \\
\hline Public hospital pharmacy & $167(51.4)$ \\
\hline Private hospital pharmacy & $15(4.6)$ \\
\hline Community pharmacy & $15(4.6)$ \\
\hline Primary care centre & $39(12)$ \\
\hline Industrial companies & $55(19.6)$ \\
\hline Academic/university & $17(5.2)$ \\
\hline Other & $17(5.2)$ \\
\hline \multicolumn{2}{|l|}{ Years of practice } \\
\hline$\leq 5$ & $125(38.5)$ \\
\hline $6-15$ & $130(40.0)$ \\
\hline
\end{tabular}

Continued 
Table 2 Job satisfaction and work commitment among the respondents

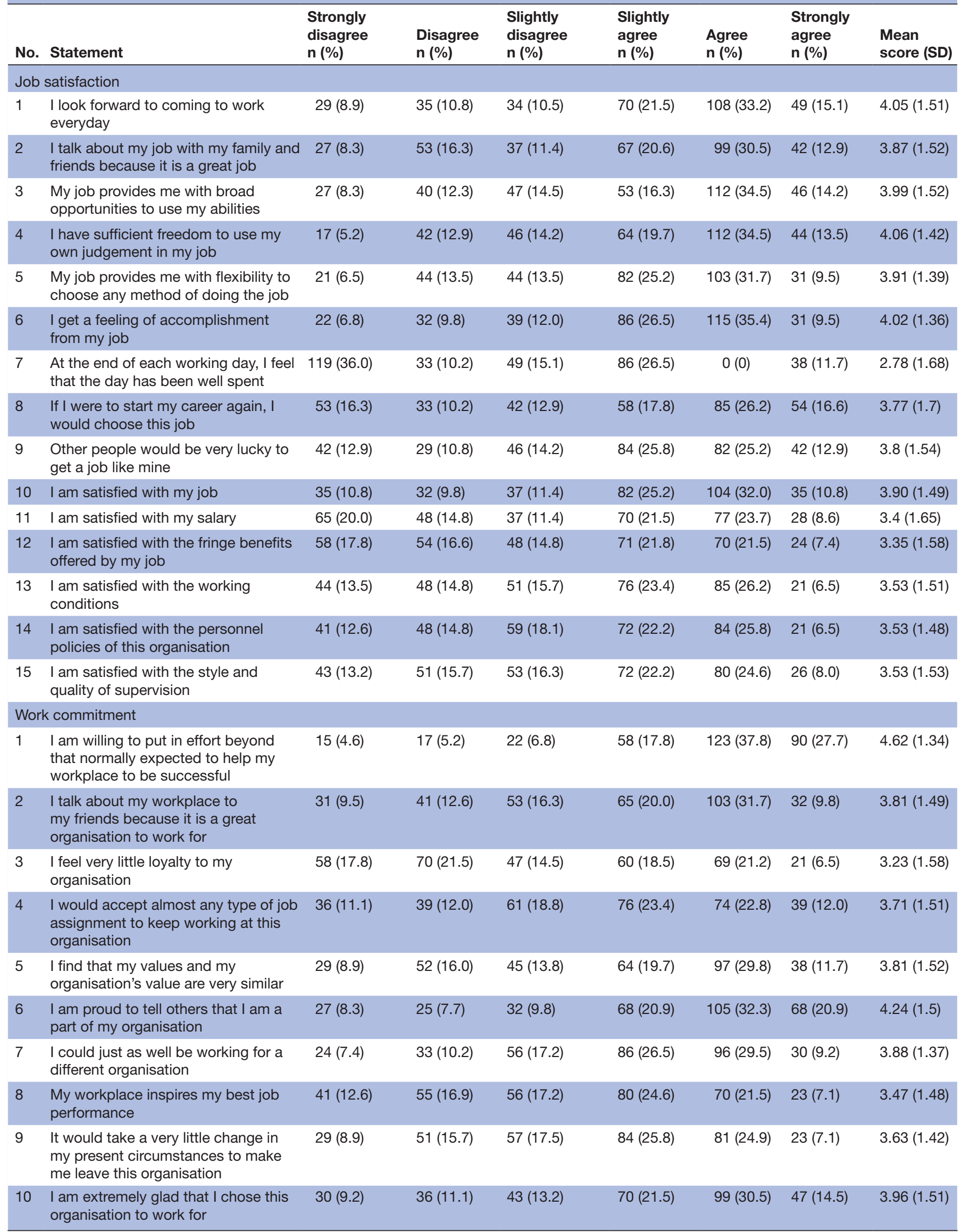


Table 2 Continued

\begin{tabular}{|c|c|c|c|c|c|c|c|c|}
\hline No. & Statement & $\begin{array}{l}\text { Strongly } \\
\text { disagree } \\
\text { n (\%) }\end{array}$ & $\begin{array}{l}\text { Disagree } \\
\text { n (\%) }\end{array}$ & $\begin{array}{l}\text { Slightly } \\
\text { disagree } \\
\text { n (\%) }\end{array}$ & $\begin{array}{l}\text { Slightly } \\
\text { agree } \\
\text { n (\%) }\end{array}$ & $\begin{array}{l}\text { Agree } \\
\mathrm{n}(\%)\end{array}$ & $\begin{array}{l}\text { Strongly } \\
\text { agree } \\
\text { n (\%) }\end{array}$ & $\begin{array}{l}\text { Mean } \\
\text { score (SD) }\end{array}$ \\
\hline 11 & $\begin{array}{l}\text { There is not much to be gained by } \\
\text { sticking with this organisation }\end{array}$ & 35 (10.8) & $60(18.5)$ & $61(18.8)$ & $84(25.8)$ & $58(17.8)$ & 27 (8.3) & $3.46(1.46)$ \\
\hline 12 & $\begin{array}{l}\text { Often, I find it difficult to agree } \\
\text { with my organisation's polices on } \\
\text { important matters relating to its } \\
\text { employees }\end{array}$ & $44(13.5)$ & $52(16.0)$ & $60(18.5)$ & $80(24.6)$ & $57(17.5)$ & 32 (9.8) & $3.46(1.52)$ \\
\hline 13 & $\begin{array}{l}\text { I really care about the fate of my } \\
\text { organisation }\end{array}$ & $20(6.2)$ & $21(6.5)$ & 35 (10.8) & $65(20.0)$ & 115 (35.4) & $69(21.2)$ & $4.36(1.41)$ \\
\hline 14 & $\begin{array}{l}\text { For me, this is the best of all possible } \\
\text { organisations to work for }\end{array}$ & 33 (10.2) & $49(15.1)$ & $56(17.2)$ & 68 (20.9) & 85 (26.2) & 34 (10.5) & $3.69(1.51)$ \\
\hline 15 & $\begin{array}{l}\text { Deciding to work for this organisation } \\
\text { was a definite mistake }\end{array}$ & $103(12.0)$ & $69(21.2)$ & $67(20.6)$ & $39(12.0)$ & 38 (11.7) & $9(2.8)$ & $2.59(1.46)$ \\
\hline
\end{tabular}

job satisfaction and work commitment. A significant association was found between age, monthly income, working hours per week, place of practice, current position and job satisfaction $(\mathrm{p}<0.05)$. Likewise, there was a significant association existed between age, nationality and level of education and work commitment $(\mathrm{p}<0.05)$.

\section{Determinants of respondents' likeliness to leave their current job}

Table 6 shows the results of a multiple logistic regression analysis of the effects of respondents' demographic characteristics, job satisfaction and work commitment on their

\begin{tabular}{lc}
\hline \multicolumn{2}{l}{$\begin{array}{l}\text { Table } 3 \\
\text { leave } a n d \text { patient safety }\end{array}$} \\
\hline \multicolumn{1}{c}{$\mathbf{n}(\%)$} \\
\hline How satisfied are you with your current job? \\
\hline Extremely dissatisfied & $23(7.1)$ \\
\hline Dissatisfied & $36(11.1)$ \\
\hline Slightly dissatisfied & $35(10.8)$ \\
\hline Slightly satisfied & $80(24.6)$ \\
\hline Satisfied & $127(39.1)$ \\
\hline Extremely satisfied & $24(4.7)$ \\
\hline How likely are you to leave your current job for any reason? \\
\hline Very unlikely & $32(9.8)$ \\
\hline Unlikely & $94(28.9)$ \\
\hline Likely & $144(44.3)$ \\
\hline Very likely & $55(16.9)$ \\
\hline How much you rate patient safety in your working place? \\
\hline Poor & $28(8.6)$ \\
\hline Fair & $51(15.7)$ \\
\hline Good & $108(33.2)$ \\
\hline Very good & $56(17.2)$ \\
\hline Excellent & $59(18.2)$ \\
\hline Not applicable & $23(7.1)$ \\
\hline &
\end{tabular}

likelihood to leave their current job. The most important predictors of intention to leave were job satisfaction and work commitment $(\mathrm{p}<0.001$ and $\mathrm{p}<0.005$, respectively). There were no significant associations between respondents' demographic characteristics and intention to leave. However, older respondents were twice as likely as younger respondents to leave their jobs. Residents and pharmacists with a diploma-level education (other) were six times more likely to leave their job than the pharmacists with bachelor or master degrees, and those with fulltime jobs were three times more likely to quit their job than those with part-time jobs, although without statistical significance.

\section{DISCUSSION}

In this study, we assessed job satisfaction and work commitment, and their determinant factors and the intention to leave, among pharmacists working at different healthcare settings in Riyadh.

\section{Job satisfaction}

Across all job satisfaction items in this survey, the respondents were moderately varied in their satisfaction. Numerous factors affected respondents' job satisfaction, including salary, workload, continuous education and development, supervision, motivation and working environment, that is work setting. These findings are largely consistent with the results of earlier studies on job satisfaction among pharmacists and other healthcare workers. ${ }^{434}$ Another study also reported that working environment, motivation and income are factors that influence job satisfaction. ${ }^{45}$ Overall, job satisfaction among the study respondents was high, but their reported likelihood to leave their current job was also high, suggesting that job satisfaction does not necessarily mean that pharmacists are not planning to leave. Lower motivation and job satisfaction, as well as the presence of work-related factors, are significantly associated with the intention to leave among healthcare workers. ${ }^{11}$ These findings are consistent with 
Table 4 Association between respondents' demographic characteristics and likelihood to stay in their current job

\begin{tabular}{|c|c|c|c|}
\hline $\begin{array}{l}\text { Demographic } \\
\text { characteristics }\end{array}$ & $\begin{array}{l}\text { Unlikely to stay } \\
n(\%)\end{array}$ & $\begin{array}{l}\text { Likely to stay } \\
n(\%)\end{array}$ & P value \\
\hline \multicolumn{4}{|l|}{ Sex } \\
\hline Male & $56(44.4)$ & $81(40.7)$ & \\
\hline Female & 70 (55.6) & 118 (59.3) & 0.565 \\
\hline \multicolumn{4}{|l|}{ Age (years) } \\
\hline$<25$ & $4(3.2)$ & $10(5)$ & \\
\hline $25-30$ & $45(35.7)$ & $71(35.7)$ & \\
\hline $31-35$ & $34(27)$ & $60(30.2)$ & 0.381 \\
\hline $36-40$ & $16(12.7)$ & $31(15.6)$ & \\
\hline$>40$ & $27(21.4)$ & $27(13.6)$ & \\
\hline \multicolumn{4}{|l|}{ Marital status } \\
\hline Single & $37(29.4)$ & 76 (38.2) & \\
\hline Married & $86(68.3)$ & $115(57.8)$ & 0.157 \\
\hline Divorced & $3(2.4)$ & $8(4)$ & \\
\hline \multicolumn{4}{|l|}{ Income/month (SR) } \\
\hline$<5000$ & $3(2.4)$ & $13(6.5)$ & \\
\hline $5000-10000$ & $16(12.7)$ & $36(18.1)$ & \\
\hline $11000-15000$ & 42 (33.3) & $75(37.7)$ & 0.047 \\
\hline$>15000$ & $65(51.6)$ & $75(37.7)$ & \\
\hline \multicolumn{4}{|l|}{ Nationality } \\
\hline Saudi Arabian & 99 (78.6) & 155 (77.9) & \\
\hline $\begin{array}{l}\text { Non-Saudi } \\
\text { Arabian }\end{array}$ & $27(21.4)$ & $44(22.1)$ & 1 \\
\hline
\end{tabular}

Highest level of education

\begin{tabular}{lccc}
$\begin{array}{l}\text { Bachelor's } \\
\text { degree }\end{array}$ & $71(56.3)$ & $100(50.3)$ \\
$\begin{array}{l}\text { Master's } \\
\text { degree }\end{array}$ & $38(30.2)$ & $56(28.1)$ & \\
$\begin{array}{l}\text { Pharm D } \\
\text { PhD }\end{array}$ & $11(8.7)$ & $25(12.6)$ & 0.218 \\
\hline $\begin{array}{l}\text { Other } \\
\text { Average hours worked per week }\end{array}$ & $8(4.0)$ & \\
\hline $\begin{array}{l}\leq 35 \\
\text { 36-44 }\end{array}$ & $15(11.9)$ & $18(9.0)$ & \\
\hline 44 & $73(57.9)$ & $98(49.2)$ & 0.106 \\
\hline $\begin{array}{l}\text { Employment status } \\
\text { Full-time }\end{array}$ & $38(30.2)$ & $83(41.7)$ & \\
\hline $\begin{array}{l}\text { Part-time } \\
\text { Place of practice }\end{array}$ & $5(4.0)$ & $193(97.0)$ \\
\hline $\begin{array}{l}\text { Public hospital } \\
\text { pharmacy }\end{array}$ & $51(40.5)$ & $116(58.3)$ \\
\hline $\begin{array}{l}\text { Private hospital } \\
\text { pharmacy }\end{array}$ & $6(4.8)$ & $9(4.5)$ \\
\hline $\begin{array}{l}\text { Community } \\
\text { pharmacy }\end{array}$ & $4(3.2)$ & $11(5.5)$ \\
\hline
\end{tabular}

Continued

\begin{tabular}{|c|c|c|c|}
\hline $\begin{array}{l}\text { Demographic } \\
\text { characteristics }\end{array}$ & $\begin{array}{l}\text { Unlikely to stay } \\
n(\%)\end{array}$ & $\begin{array}{l}\text { Likely to stay } \\
n(\%)\end{array}$ & $P$ value \\
\hline $\begin{array}{l}\text { Primary care } \\
\text { centre }\end{array}$ & $18(14.3)$ & $21(10.6)$ & \\
\hline $\begin{array}{l}\text { Industrial } \\
\text { companies }\end{array}$ & $28(22.2)$ & 27 (13.6) & 0.026 \\
\hline $\begin{array}{l}\text { Academic/ } \\
\text { university }\end{array}$ & $10(7.1)$ & 7 (3.5) & \\
\hline Other & $9(7.1)$ & $8(4)$ & \\
\hline \multicolumn{4}{|l|}{ Years of practice } \\
\hline$\leq 5$ & 44 (34.9) & $81(40.7)$ & \\
\hline $6-15$ & 49 (38.9) & $81(40.7)$ & \\
\hline $16-20$ & 17 (13.5) & 25 (12.6) & 0.19 \\
\hline$>20$ & $16(12.7)$ & $12(6)$ & \\
\hline \multicolumn{4}{|l|}{ Current position } \\
\hline $\begin{array}{l}\text { Pharmacist } \\
\text { manager/ } \\
\text { supervisor }\end{array}$ & 47 (37.3) & $49(25.0)$ & \\
\hline $\begin{array}{l}\text { Pharmacist } \\
\text { staff }\end{array}$ & $58(46.0)$ & 124 (63.3) & 0.010 \\
\hline Other & $21(16.7)$ & $23(11.7)$ & \\
\hline
\end{tabular}

Pharm D, Doctor of Pharmacy; PhD, Doctor of Philosophy; SR, Saudi riyals.

a study on job satisfaction, sources of stress and workload among New Zealand healthcare professionals, in which pharmacists were significantly less satisfied as a result of job-related stress. ${ }^{12}$ The greatest level of job satisfaction was reported by pharmacists with a higher income. ${ }^{23} \mathrm{In}$ some studies, job dissatisfaction among pharmacists was found to be related to their place of work, especially among pharmacists working in community chain pharmacies. Conversely, pharmacists working in hospital pharmacies have a better level of satisfaction than those working in other practice settings. ${ }^{240}$ A high degree of job satisfaction may help to lower employee absenteeism and consequently turnover intentions. ${ }^{28}$

\section{Work commitment}

In this study, the majority of respondents expressed commitment to their work, showing qualities such as loyalty, workplace environment, agreement with organisation policies and interest in organisational procedures and fate. These findings have commonalities with those of a previous study, which defined three basic components necessary for employees' work commitment: loyalty, acceptance of an organisations' policies and good leadership behaviour. ${ }^{46}$ Another study demonstrated that the interpersonal environment of a work setting has an effect on nurses' work commitment. ${ }^{47}$ These different findings emphasise that enhancing employee empowerment has a positive effect on organisational trust and commitment. ${ }^{48} \mathrm{~A}$ previous study 
Open access

Table 5 Effect of respondents' demographic characteristics on job satisfaction and work commitment

\begin{tabular}{|c|c|c|c|c|}
\hline Demographic characteristics & $\begin{array}{l}\text { Job satisfaction } \\
\text { Median (IQR) }\end{array}$ & $P$ value & $\begin{array}{l}\text { Work commitment } \\
\text { Median (IQR) }\end{array}$ & $P$ value \\
\hline \multicolumn{5}{|l|}{ Sex } \\
\hline Male & $61(47-70)$ & 0.154 & $58(49-65)$ & 0.721 \\
\hline Female & $55(44-68)$ & & $57(50-64)$ & \\
\hline \multicolumn{5}{|l|}{ Age (years) } \\
\hline$<25$ & $60(34-67)$ & & $60(41-63)$ & \\
\hline $25-30$ & $59(46-71)$ & & $58(52-65)$ & \\
\hline $31-35$ & $56(42-65)$ & 0.008 & $56(49-64)$ & 0.038 \\
\hline $36-40$ & $52(34-68)$ & & $53(45-63)$ & \\
\hline$>40$ & $66(53-71)$ & & $60(54-67)$ & \\
\hline \multicolumn{5}{|l|}{ Marital status } \\
\hline Single & $57(42-67)$ & & $58(50-64)$ & \\
\hline Married & $59(47-71)$ & 0.328 & $57(50-65)$ & 0.962 \\
\hline Divorced & $57(48-65)$ & & $59(46-65)$ & \\
\hline \multicolumn{5}{|l|}{ Income/month (SR) } \\
\hline$<5000$ & $52(28-59)$ & & $57(36-63)$ & \\
\hline $5000-10000$ & $55(45-70)$ & 0.006 & $59(52-69)$ & 0.091 \\
\hline $11000-15000$ & $56(39-68)$ & & $56(46.5-64)$ & \\
\hline$>15000$ & $60(50-71)$ & & $58(50-65)$ & \\
\hline \multicolumn{5}{|l|}{ Nationality } \\
\hline Saudi Arabian & $58(44-68)$ & 0.464 & $57(49-64)$ & 0.014 \\
\hline Non-Saudi Arabian & $59(48-70)$ & & $60(54-67)$ & \\
\hline \multicolumn{5}{|l|}{ Highest level of education } \\
\hline Bachelor's degree & $60(49-70)$ & & $59(52-66)$ & \\
\hline Master's degree & $58(43-69)$ & & $55(49-66)$ & \\
\hline Pharm D & $55(38-68)$ & 0.065 & $54(44-6)$ & 0.017 \\
\hline $\mathrm{PhD}$ & $52(43-64)$ & & $51(45-61)$ & \\
\hline Other & $50(32-53)$ & & $58(45-67)$ & \\
\hline \multicolumn{5}{|l|}{ Average hours worked per week } \\
\hline$\leq 35$ & $59(38-67)$ & & $56.5(40-68)$ & \\
\hline $36-44$ & $61(49-71)$ & 0.001 & $58(51-66)$ & 0.281 \\
\hline$>44$ & $53(39-65)$ & & $57(49-63)$ & \\
\hline \multicolumn{5}{|l|}{ Employment status } \\
\hline Full-time & $58(46-69)$ & 0.962 & $57(50-65)$ & 0.695 \\
\hline Part-time & $60(42-64)$ & & $54(48-66)$ & \\
\hline \multicolumn{5}{|l|}{ Place of practice } \\
\hline Public hospital pharmacy & $54(39-65)$ & & $57(49-64)$ & \\
\hline Private hospital pharmacy & 55 (38-69) & & $58(47-74)$ & \\
\hline Community pharmacy & $59(43-67)$ & & $58(54-61)$ & \\
\hline Primary care centre & $55(43-71)$ & $<0.001$ & $58(45-69)$ & 0.599 \\
\hline Industrial companies & $68(58-73)$ & & $59(56-64)$ & \\
\hline Academic/university & $60(45-71)$ & & $57(50-69)$ & \\
\hline Other & $60(48-74)$ & & $53(49-67)$ & \\
\hline \multicolumn{5}{|l|}{ Years of practice } \\
\hline$\leq 5$ & $57(43-70)$ & & $57(47-64)$ & \\
\hline
\end{tabular}


Table 5 Continued

\begin{tabular}{|c|c|c|c|c|}
\hline Demographic characteristics & $\begin{array}{l}\text { Job satisfaction } \\
\text { Median (IQR) }\end{array}$ & $P$ value & $\begin{array}{l}\text { Work commitment } \\
\text { Median (IQR) }\end{array}$ & $P$ value \\
\hline $6-15$ & $58(43-68)$ & 0.027 & $56(50-64)$ & 0.123 \\
\hline$>20$ & $66(57-73)$ & & $61(54-69)$ & \\
\hline \multicolumn{5}{|l|}{ Current position } \\
\hline Pharmacist staff & $54(40-67)$ & 0.001 & $57(47-64)$ & 0.284 \\
\hline Other & $60(49-71)$ & & $57(50-64)$ & \\
\hline
\end{tabular}

IQR, interquartile range; Pharm D, Doctor of Pharmacy; PhD, Doctor of Philosophy; SR, Saudi riyals.

found that job turnover intention was mediated by organisational commitment. ${ }^{34}$ Organisational commitment influences the willingness of employees to leave.
This is consistent with the observation that overall job satisfaction and work commitment affects job turnover rate. $^{49}$

Table 6 Multiple logistic regression analysis of the effects of respondents' demographic characteristics, job satisfaction and work commitment on their likelihood to leave their current job

\begin{tabular}{|c|c|c|c|}
\hline Variables & Coefficient (SE) & OR (95\% CI) & $P$ value \\
\hline Job satisfaction & $-0.08(0.013)$ & 0.923 (0.899 to 0.947$)$ & $<0.001$ \\
\hline Work commitment & $0.043(0.016)$ & 1.044 (1.014 to 1.08$)$ & 0.004 \\
\hline \multicolumn{4}{|l|}{ Monthly income (SR) } \\
\hline$<5000$ & - & - & - \\
\hline 5000-10000 & $0.171(0.786)$ & 1.187 (0.255 to 5.535$)$ & 0.827 \\
\hline $11000-15000$ & $-0.427(0.759)$ & 0.653 (0.147 to 2.889$)$ & 0.574 \\
\hline$>15000$ & $-0.328(0.783)$ & 0.721 (0.155 to 3.245$)$ & 0.676 \\
\hline \multicolumn{4}{|l|}{ Place of pharmacy practice } \\
\hline Public hospital pharmacy & - & - & - \\
\hline Private hospital pharmacy & $-0.865(0.670)$ & 0.421 (0.113 to 1.567$)$ & 0.197 \\
\hline Community pharmacy & $0.097(0.706)$ & 1.101 (0.276 to 4.397$)$ & 0.891 \\
\hline Primary care centre pharmacy & $-0.587(0.416)$ & 0.556 (0.246 to 1.256$)$ & 0.158 \\
\hline Industrial company & $-0.254(0.421)$ & 0.776 (0.340 to 1.771$)$ & 0.546 \\
\hline Academic/university hospital & $-1.203(0.708)$ & $0.300(0.075$ to 1.203$)$ & 0.089 \\
\hline Other & $-0.846(0.644)$ & 0.429 (0.122 to 1.516$)$ & 0.189 \\
\hline \multicolumn{4}{|l|}{ Years of practice } \\
\hline$\leq 5$ & - & - & - \\
\hline $6-15$ & $-0.053(0.329)$ & 0.948 (0.498 to 1.807$)$ & 0.872 \\
\hline $16-20$ & $-0.280(0.483)$ & 0.756 (0.293 to 1.948$)$ & 0.562 \\
\hline$>20$ & $-0.283(0.946)$ & 0.753 (0.257 to 2.212$)$ & 0.606 \\
\hline \multicolumn{4}{|l|}{ Current position } \\
\hline Pharmacy manager/supervisor & - & - & \\
\hline Pharmacist & $0.249(0.344)$ & 1.283 (0.653 to 2.520$)$ & 0.470 \\
\hline Other & $0.319(0.500)$ & 1.376 (0.516 to 3.666$)$ & 0.523 \\
\hline Constant & $3.089(1.25)$ & 21.959 & 0.041 \\
\hline Pseudo $R^{2}$ & & 0.212 & \\
\hline -Log likelihood & & 354.488 & \\
\hline
\end{tabular}

OR, odds ratio; Pharm D, Doctor of Pharmacy; PhD, Doctor of Philosophy; SE, standard error; SR, Saudi riyals. 


\section{Respondents' likelihood to leave their current job}

Although the study findings show that the pharmacists were satisfied with and committed to their current jobs, most stated that they were likely to leave. This is largely consistent with the findings of a study involving family physicians in the UK, in which high levels of job satisfaction did not mitigate their intentions to leave the profession. ${ }^{50}$ The top three significant factors affecting our respondents' likelihood to stay in their current jobs were monthly income, place of practice and current position. This is partially in agreement with a previous study assessing healthcare workers' intentions to leave, which showed that pay and benefits and place of practice were significantly predictive of nurses' intentions to leave their current employment. ${ }^{51}$ Pharmacists working in community sectors have a higher tendency to intend to quit than pharmacists working in other sectors. ${ }^{19}$ These findings are similar to those of a study of Chinese physicians, who had a greater tendency to quit their jobs if they had a low income than a higher income or a technical position than a managerial position. ${ }^{52}$ Several studies have emphasised that poor salary is one of the primary predictors of intention to leave among pharmacists and other healthcare workers. ${ }^{215354}$ A pharmacist's position has a significant effect on job turnover intention. ${ }^{55}$ This is especially true among independent pharmacy owners, who demonstrate more positive attitudes toward their work than other pharmacists positions. ${ }^{34}$ In contrast, excessive employee workloads and poor relationships with supervisors play an important role in intentions to leave. ${ }^{53} 56$ In our study, demographic characteristics such as sex and age had no influence on pharmacists' likelihood to stay in their current job. These results are similar to those of a study involving physicians, which found that age and sex have no significant effect on intention to leave. ${ }^{52}$ In general, women have a higher annual intention to leave than men. ${ }^{21}$ Our findings differ from those of some other studies, in which sex and age are primary factors affecting pharmacists' intentions to quit their profession. ${ }^{19}$ Other studies have also found that predictors such as relocation and layoffs were common reasons for the high turnover rate of pharmacists. ${ }^{38}$

\section{Associations and determinate factors}

The analysis of the study findings showed that respondents' characteristics such as age, income, workload, practice setting, experience and current position were significantly predictive of their level of job satisfaction. Likewise, a previous study found that working in hospitals and independent settings influences the level of job satisfaction among pharmacists. ${ }^{22}$ Similarly, another study showed that age, income and place of practice are significant predictors of job satisfaction. However, work experience is not a significant determinant of job satisfaction. ${ }^{16}$ Our results also demonstrated that respondents' sex, marital status, nationality, level of education and employment status were not among the factors that influenced job satisfaction. These results are consistent with those of a study conducted at a Ministry of Health hospital in Saudi Arabia. ${ }^{57}$ Sex was previously identified as a predictor of job satisfaction, especially in female pharmacists, but this was not the case our study. ${ }^{19}$ Suleiman ${ }^{42}$ defined a series of factors that influence job satisfaction, including working conditions, the nature of the work, salary, opportunities and management. In the UK, two studies emphasised that workload and high-pressure working environments contribute to a decrease in pharmacists' job satisfaction. ${ }^{18}{ }^{23}$ Consistently, another study performed in Saudi Arabia agreed that workload is an important source of dissatisfaction among physicians in primary healthcare centres. ${ }^{58}$ Another factor affecting job satisfaction identified in a previous study was being of Saudi Arabian nationality, but nationality had no influence on job satisfaction in this study. ${ }^{13}$ Pharmacists who work in administrative offices have higher job satisfaction than those working in health clinics and hospitals. ${ }^{43}$ Indeed, pharmacists' positions were the factor most significantly associated with high job satisfaction. ${ }^{59}$

Regarding work commitment, our study identified three significant predictors: age, nationality and level of education. Age had a high correlation with employee organisational attachment. Younger pharmacists were less committed to their work, especially those with less than 7 years of employment. ${ }^{32}$ In contrast, a US study emphasised that age has no effect on career or organisational commitment. Management support has a positive effect on work commitment. ${ }^{33}$ Improved work-related attitudes were also found to increase work commitment. ${ }^{33}{ }^{34}$ In addition, increased access to knowledge, development, support and opportunities increase organisational commitment. ${ }^{60}$ Among nurses, higher level of education has a positive effect on organisational commitment and job satisfaction. ${ }^{61}$ Training and professional development are also considered important aspects of job satisfaction by pharmacists. ${ }^{43}$ In our study, demographic characteristics such as sex, marital status, income, workload, practice setting and years of experience had no significant effect on pharmacists' commitment. This opposes a previous finding that married pharmacists are more committed to their work. ${ }^{20}$ Another study found that workload has a great impact on lowering employees' organisational commitments. ${ }^{56}$

Our study shows that job satisfaction and work commitment are significantly related to pharmacists' intentions to leave. In contrast, a previous study reported that high job satisfaction and work commitment have an inverse association with the intention to leave.$^{56}$ Another study found that high levels of job satisfaction and work commitment decrease the likelihood of job turnover intention. ${ }^{34}$ Opposing outcomes were found in a study conducted in Pakistan on the determinants of employees' intentions to leave, in which organisational commitment, job satisfaction and intention to leave were not significantly associated. ${ }^{56}$ Job turnover intentions among pharmacy faculty staff are influenced by organisational commitment. ${ }^{53}$ Among physicians, previous results have shown that job 
satisfaction is an important predictor of their intentions to leave their profession. ${ }^{50}$ Furthermore, our results did not show any significant association between respondents' demographic characteristics and their intentions to leave. Working hours, marital status, income and continuation of education influence the rate of job turnover among hospital pharmacists. ${ }^{20}$ Among nurses, a high level of education and an equitable workload equate to greater commitment, productivity and effectiveness in their organisations, and thus they are less likely to leave their jobs. ${ }^{61}$ Another study found that productive and effective organisation is generated by a high level of employee satisfaction and commitment. ${ }^{61}$ Furthermore, an earlier study demonstrated that a high level of job satisfaction equates to reduced employee absenteeism and intentions to leave. ${ }^{42}$

\section{Limitation and strengths}

This study had some limitations that can be summarised as follows. Because of the study design used, there is a chance that the associations identified may have been misinterpreted. The limited duration and timing of data collection prevented us from getting more responses and cooperation from more pharmaceutical companies, community chain pharmacies and pharmacies at private hospitals to cover most practice settings in Riyadh. Therefore, it may not be possible to generalise our results, which analysed only pharmacists in Riyadh, to all pharmacists in other parts of Saudi Arabia. Furthermore, our results were based on the self-reported perceptions of the study's participants and are therefore subject to bias. Despite these limitations, the study has provided interesting baseline results, which will help to inform better research in future.

Regarding the strengths of the study, the Saudi Commission for Health Specialties provided a list of contact details for all licensed pharmacists in Riyadh. Web-based surveys facilitated data collection and reduced costs. No other studies have investigated job satisfaction, work commitment and intention to leave among pharmacists in Saudi Arabia. Previous studies have focused on healthcare workers other than pharmacists.

\section{CONCLUSION}

Our results reveal differing levels of job satisfaction and work commitment between pharmacists working in different practice settings in Riyadh. Our findings indicate that a significant relationship exists between pharmacists' job satisfaction and work commitment and their intention to leave. In general, the pharmacists surveyed were satisfied with their jobs, but at the same time, they expressed a desire to leave their current positions. Further research is required to determine why the intention to leave is increasing among pharmacists in Saudi Arabia.

Acknowledgements The authors are thankful to all the healthcare staff who participated in the study.
Contributors NA: designed the study protocol, developed study tool, reviewed results and drafted the manuscript. KA: proposed the study idea, supervised the whole study, analysed the data and revised the drafted manuscript. Both authors have read and approved the final manuscript.

Funding The authors have not declared a specific grant for this research from any funding agency in the public, commercial or not-for-profit sectors.

Competing interests None declared.

Patient consent for publication Not required.

Ethics approval The research ethics committee of the King Abdullah International Medical Research Center (KAIMRC) at the King Abdul-Aziz Medical City approved the study and granted IRB approval (protocol number SP17/116/R). The consent form was attached with each questionnaire to obtain a well-informed decision by participants to take part in this study voluntarily.

Provenance and peer review Not commissioned; externally peer reviewed.

Data availability statement Data are available upon reasonable request.

Open access This is an open access article distributed in accordance with the Creative Commons Attribution Non Commercial (CC BY-NC 4.0) license, which permits others to distribute, remix, adapt, build upon this work non-commercially, and license their derivative works on different terms, provided the original work is properly cited, appropriate credit is given, any changes made indicated, and the use is non-commercial. See: http://creativecommons.org/licenses/by-nc/4.0/.

\section{REFERENCES}

1. Statistics BoL. Occupational outlook Handbook, pharmacy technicians. U.S, 2002-03.

2. Health UDo, Services H. The pharmacist workforce: A study of the supply and demand for pharmacists. In: Report to Congress, 2000.

3. Haseeb A, Elrggal M. Recommendations for the role of the pharmacist in Saudi Arabia. Arch Pharm Pract 2013;4.

4. Al-jedai A, Qaisi S, Al-meman A. Pharmacy practice and the health care system in Saudi Arabia. Can J Hosp Pharm 2016;69:231.

5. Fitzenz J. It's costly to lose good employees. Workforce 1997;76:50-1.

6. Spector PE. Job satisfaction: application, assessment, causes, and consequences: SAGE publications, 1997.

7. Parent-Thirion A. Fourth European working conditions survey: European foundation for the improvement of living and working conditions, 2007

8. Almutairi D, Moradi E, Idrus D. Factors influencing turnover among Saudi nurses. In: A literature review, 2010: 1-13.

9. Bawakid K, Abdulrashid O, Mandoura N, et al. Burnout of physicians working in primary health care centers under Ministry of health Jeddah, Saudi Arabia. Cureus 2017;9.

10. Open E, Yitayal M, Gebreslassie M. Turnover intention and associated factors among health professionals in University of Gondar referral Hospital, Northwest Ethiopia. Int J Econ Manag Sci 2014;3:1-4.

11. Bonenberger $\mathrm{M}$, Aikins $\mathrm{M}$, Akweongo $\mathrm{P}$, et al. The effects of health worker motivation and job satisfaction on turnover intention in Ghana: a cross-sectional study. Hum Resour Health 2014;12:43.

12. Dowell AC, Westcott T, McLeod DK, et al. A survey of job satisfaction, sources of stress and psychological symptoms among New Zealand health professionals. N Z Med J 2001;114:540-3.

13. A-HAe al. Job stress and job satisfaction among health care professionals. Eur Sci J 2014;10.

14. Lu Y, Hu X-M, Huang X-L, Huang X-L, et al. Job satisfaction and associated factors among healthcare staff: a cross-sectional study in Guangdong Province, China. BMJ Open 2016;6:e011388.

15. Mott DA, Doucette WR, Gaither CA, et al. Pharmacists' attitudes toward worklife: results from a national survey of pharmacists. J Am Pharm Assoc 2004;44:326-36.

16. Liu CS, White L. Key determinants of hospital pharmacy staff's job satisfaction. Res Social Adm Pharm 2011;7:51-63.

17. Bourne RS, Baqir W, Onatade R. Pharmacist independent prescribing in secondary care: opportunities and challenges. Int $J$ Clin Pharm 2016;38:1-6.

18. Gidman WK, Hassell K, Day J, et al. The impact of increasing workloads and role expansion on female community pharmacists in the United Kingdom. Res Social Adm Pharm 2007;3:285-302.

19. Seston E, Hassell K, Ferguson J, et al. Exploring the relationship between pharmacists' job satisfaction, intention to quit the profession, and actual quitting. Res Social Adm Pharm 2009;5:121-32. 
20. Smith SN, Stewart JE, Grussing PG. Factors influencing the rate of job turnover among hospital pharmacists. Am J Health Syst Pharm 1986;43:1936-41.

21. Mott DA. Pharmacist job turnover, length of service, and reasons for leaving, 1983-1997. Am J Health Syst Pharm 2000;57:975-84.

22. McCann L, Hughes CM, Adair CG, et al. Assessing job satisfaction and stress among pharmacists in Northern Ireland. Pharm World Sci 2009;31:188-94.

23. Hardigan $P$, Carvajal $M$, et al. Job satisfaction among practicing pharmacists: a Rasch analysis. Internet Journal of Allied Health Sciences and Practice 2007;5.

24. Maio V, Goldfarb NI, et al. Pharmacists' job satisfaction: variation by practice setting, 2004.

25. Lea VM, Corlett SA, Rodgers RM. Workload and its impact on community pharmacists' job satisfaction and stress: a review of the literature. Int J Pharm Pract 2012;20:259-71.

26. Schafheutle El, Seston EM, Hassell K. Factors influencing pharmacist performance: a review of the peer-reviewed literature. Health Policy 2011;102:178-92.

27. Bawazir S. Job satisfaction in Saudi community pharmacists letter. $J$ Pharm Pract Res 2005;35.

28. Aziri B. Job satisfaction: a literature review. Manag Res Pract 2011;3.

29. McHugh PP. Pharmacists' attitudes regarding quality of worklife. $J$ Am Pharm Assoc 1999;39:667-76.

30. Hall LH, Johnson J, Watt I, et al. Healthcare staff wellbeing, burnout, and patient safety: a systematic review. PLoS One 2016;11:e0159015.

31. Biksegn A, Kenfe T, Matiwos S, et al. Burnout Status at Work among Health Care Professionals in aTertiary Hospital. Ethiop J Health Sci 2016;26:101-8.

32. Stewart JE, Smith SN. Work expectations and organizational attachment of hospital pharmacists. Am J Health Syst Pharm 1987;44:1105-10.

33. Kong SX. Predictors of organizational and career commitment among Illinois pharmacists. Am J Health Syst Pharm 1995;52:2005-11.

34. Gaither CA. Career commitment: a mediator of the effects of job stress on pharmacists' work-related attitudes. J Am Pharm Assoc 1999;39:353-61.

35. Guchelaar H-J, Colen HBB, Kalmeijer MD, et al. Medication errors: hospital pharmacist perspective. Drugs 2005;65:1735-46.

36. Benjamin DM. Reducing medication errors and increasing patient safety: case studies in clinical pharmacology. J Clin Pharmacol 2003;43:768-83.

37. Teinilä T, Grönroos V, Airaksinen M. A system approach to dispensing errors: a national study on perceptions of the Finnish community pharmacists. Pharm World Sci 2008;30:823-33.

38. Samsuri SE, Pei Lin L, Fahrni ML. Safety culture perceptions of pharmacists in Malaysian hospitals and health clinics: a multicentre assessment using the Safety Attitudes Questionnaire. BMJ Open 2015;5:e008889.

39. Chui MA, Look KA, Mott DA. The association of subjective workload dimensions on quality of care and pharmacist quality of work life. Res Social Adm Pharm 2014;10:328-40.

40. Al Khalidi D, Wazaify M. Assessment of pharmacists' job satisfaction and job related stress in Amman. Int J Clin Pharm 2013;35:821-8.

41. Al-Worafi YM. Pharmacy practice and its challenges in Yemen. Australas Med J 2014;7:17-23.

42. Suleiman A. Stress and job satisfaction among pharmacists in Riyadh, Saudi Arabia. Saudi J Med Med Sci 2015;3.
43. Chua GN, Yee LJ, Sim BA, et al. Job satisfaction, organisation commitment and retention in the public workforce: a survey among pharmacists in Malaysia. Int J Pharm Pract 2014;22:265-74.

44. Salahuddin E, Ronis KA. Assessment of job satisfaction among registered pharmacists working in public and private hospitals of Multan. Pak J Public Health 2016;6.

45. Peters $\mathrm{DH}$, Chakraborty $\mathrm{S}$, Mahapatra $\mathrm{P}$, et al. Job satisfaction and motivation of health workers in public and private sectors: crosssectional analysis from two Indian states. Hum Resour Health 2010;8:27.

46. Yousef DA. Organizational commitment: a mediator of the relationships of leadership behavior with job satisfaction and performance in a non-western country. J Manag Psychol 2000;15:6-24.

47. Leiter MP, Maslach C. The impact of interpersonal environment on burnout and organizational commitment. J Organ Behav 1988;9:297-308.

48. Laschinger HK, Finegan J, Shamian J. The impact of workplace empowerment, organizational trust on staff nurses' work satisfaction and organizational commitment. Health Care Manage Rev;26:59-85.

49. CAMP SD. Assessing the effects of organizational commitment and job satisfaction on turnover: An event history approach. Prison $J$ 1994:74:279-305.

50. Hann M, Reeves D, Sibbald B. Relationships between job satisfaction, intentions to leave family practice and actually leaving among family physicians in England. Eur J Public Health 2011;21:499-503.

51. Chan MF, Luk AL, Leong SM, et al. Factors influencing Macao nurses' intention to leave current employment. J Clin Nurs 2009;18:893-901.

52. Zhang $Y$, Feng $X$. The relationship between job satisfaction, burnout, and turnover intention among physicians from urban state-owned medical institutions in Hubei, China: a cross-sectional study. BMC Health Serv Res 2011;11:235.

53. Conklin $\mathrm{MH}$, Desselle SP. Job turnover intentions among pharmacy faculty. Am J Pharm Educ 2007;71:62.

54. Chan E-Y, Morrison P. Factors influencing the retention and turnover intentions of registered nurses in a Singapore hospital. Nurs Health Sci 2000;2:113-21.

55. O'Neill JL, Gaither CA. Investigating the relationship between the practice of pharmaceutical care, construed external image, organizational identification, and job turnover intention of community pharmacists. Res Social Adm Pharm 2007;3:438-63.

56. Arshad MQ, Munir HMA, et al. Determinants of employees intention to leave: a study from Pakistan. Int J Hum Resour Stud 2014;4.

57. AL-OMAR B. Sources of work-stress among hospital-staff at the Saudi MOH. Eco 2003;17:3-16.

58. Kalantan KA, Al-Taweel AA, Abdul Ghani H. Factors influencing job satisfaction among primary health care (PHC) physicians in Riyadh, Saudi Arabia. Ann Saudi Med 1999;19:424-6.

59. Exploring facets of job satisfaction among U.S. Hospita; pharmacists. Am J Health Syst Pharm:301-657.

60. Kahaleh A, Gaither $\mathrm{C}$. The effects of work setting on pharmacists empowerment and organizational behaviors. Res Social Adm Pharm 2007;3:199-222.

61. Mahmoud A. A study of nurses' job satisfaction: the relationship to organizational commitment, perceived organizational support, transactional leadership, transformational leadership, and level of education. Eur J Sci Res 2008;22:286-95. 